\title{
WHAT IS BEING DONE FOR A GENDER-FRIENDLY CAMPUS CLIMATE? UNITED STATES AND TURKEY AS A CASE
}

\author{
Özlem Belkıs ${ }^{* 1}$ 凹 iD , Ayşe Geysu Menteş ${ }^{2}$ iD \\ ${ }^{* 1}$ Associate Professor, Dokuz Eylul University, Fine Arts Faculty, Turkey \\ 2 Freelance Researcher, USA
}

DOI: https://doi.org/10.29121/granthaalayah.v9.i2.2021.3278

Article Type: Research Article

Article Citation: Özlem Belkıs, and Ayşe Geysu Menteş. (2021). WHAT IS BEING DONE FOR A GENDERFRIENDLY CAMPUS CLIMATE? UNITED STATES AND TURKEY AS A CASE. International Journal of Research -GRANTHAALAYAH, 9(2), 11-21.

https://doi.org/10.29121/granthaa layah.v9.i2.2021.3278

Received Date: 24 January 2021

Accepted Date: 18 February 2021

Keywords:

Gender Friendly Campus Climate Gender Equality

Sexual Harassment

\begin{abstract}
Today, the process of learning is as important as the content of it as learning environments are part of the individual development. A genderfriendly campus climate that aims to create equal conditions for each student and aspires to prevent exclusion and marginalization caused by gender or sexual orientation is extremely important for the efficiency of education and individual development. Different organizations such as university administrations, feminist organizations, student and academic groups carry out various studies to constitute and maintain a genderfriendly campus climate. This article studies the collective implementations the US and Turkish Universities have been conducting to create a gender-friendly campus climate in the years of 2018 and 2019. At the end of the study, it is observed that the public sensitivity caused by adversity experienced by individuals has been an important aspect for the institutions to take action towards a gender-friendly campus climate. Moreover, research and studies of leading feminist academics have been an important fraction to guiding these steps. Also it has been enquired that 'a standard implementation system to create a Gender-friendly campus climate' cannot be the subject matter for every institution regardless of the country or location works in accordance within its own culture and structure.
\end{abstract}

\section{INTRODUCTION}

The increase in conservative tendencies also increases the discriminatory attitudes and thoughts in the aspect of gender. Gender based inequality is a strong historical habit that we try to eliminate within the structure of contemporary society. History is crammed with examples of inequalities based on gender and the struggle against them. We are mindful that gender-based inequality has many negative consequences. This form of inequality causes not only violations of educational, health and economical rights but it also hampers the individual's ability to express themselves and leads them to exclude themselves from society. Despite numerous research and knowledge on the subject the gender gap is far from being closed.

The matter of equality has been one of the fundamental arguments in international law with the establishment of United Nations (Acar \& Ertürk, 2011). Gender inequality is an issue on the agenda with the actions of feminism and gender equality groups as they try to eradicate this issue. With the Beijing Declaration of 1995, solutions such as promoting gender equality and empowering women were put forward as a global strategy (Acar \& Ertürk, 2011). Two years later, the Economic and Social Council (ECOSOC) of the United Nations proposed mainstreaming using

(C) 2021 The Author(s). This is an open access article distributed under the terms of the Creative Commons Attribution License, which permits unrestricted use, distribution, and reproduction in any medium, provided the original author and source are credited. 
the gender equality approach in legislation, policies and programs (Puri, 2017). It would be naive to say that these solution strategies have been used effectively and widely. Even though the problem has not been resolved, there has been substantial progress since 1945. Today, one of the main investigations and action parameters of international and supranational (transnational) organizations such as the United Nations (UN), the World Health Organization (WHO) and the World Economic Forum (WEF) is still gender inequality. Unfortunately, the gender gap still looks discerning.

One of the areas where gender inequality should be eliminated, perhaps the most important, is in establishments of higher learning. Educational environments are, of course, not just about the written curriculum, and gender stereotypes can be ineffectual in these settings. As a result of research, we are aware that the way students experience campus life affects their learning and developmental processes (Pascarella \& Terenzini, 2005). Therefore, we come across two concepts in the context of an equal educational environment for all individuals: hidden curriculum and campus climate. Hidden curriculum, defined as behavioral forms or attitudes learned at school but not in the written curriculum which affects all kinds of learning and development processes and includes sexist behaviors that are not expressed in words (Jackson P. , 1990) (Hernández , González, \& Sánchez, 2013). Classroom or school climate can be defined as the social flora of the educational environment and is effective in both learning and individual development. Chang (2003) in her research found that students who were exposed to discrimination, psychological or physical harassment of a group or individual on campus throughout their school life also had low participation in education. Various studies also show that students experience campus climate differently according to their belonging to social groups and according to their exclusion from such groups (Miller, Anderson, Cannon, Perez , \& Moore, 1998) (Hutchinson, Raymond, \& Black, 2008). The negative consequences of gender or racial discrimination within the campus climate have been exposed by research (D'Augelli \& Hershberger, 1993) (Reid \& Radhakrishnan, 2003) (Rankin \& Reason, 2005). In addition, campus experience has an important effect on the identity development of an individual of university age (Jones \& Abes, 2013) (Magolda, 2009) and the students who feel that they are not being represented properly or who feel disenfranchised get stressed and become alienated from campus life and eventually have lower success rates (Zimmerman \& Herridge, 1970) (Seelman, Woodford, \& Nicolazzo, 2017) (Squire \& Norris, 2014). It seems that a gender-friendly campus climate, which offers equal conditions for each student, and prevents exclusion and being marginalized because of their gender or sexual orientation, is extremely important for the efficiency of education and individual development. Studies in this field are carried out in many ways.

Corporate university administrations, student communities and activists, faculty, unions or government, feminist, or LGBTQ+ groups occasionally intersect and collaborate, but often work separately. It is useful and important to evaluate and review these studies. That is the reason our article aims to cover the studies and regulations that are done corporately in USA and Turkish universities for gender-friendly campus climates. We witness that the rising conservatism in both countries supports patriarchal points of view, thinking, behavior and expression. We know that patriarchal structure and gender-based exclusion, discrimination and violence are directly related to one another. Therefore, we hope that it will be a great review for the reader to examine what has been done for the establishment of equality, especially gender equality, in different societies.

\section{DESCRIPTIONS AND FRAME: GENDER FRIENDLY CAMPUS CLIMATE, USA AND TURKEY}

Gender is the largest category on earth (Dökmen, 2010) and therefore it is the most common form of discrimination. Various studies are being carried out to remove this form of discrimination from educational environments and to provide a gender-friendly campus climate (GFCC). The GFCC notion started appearing in the United States in the 1970's, and it has become widespread with the studied projects and research (Cantor, et al., 2015) (Hutchinson, Raymond, \& Black, 2008). It has been adopted the first time in 2011 in Turkey among 11 universities and officially it has been included in the government agenda at the Gender Conscious University Seminar held by YÖK in 2015 and later followed by various projects in the Women's Rights and Issues Research Centers of a few universities (Uygur, et al., 2018).

Experiencing unwanted situations on campus raises the concern about campus safety (Lott, Reilly, \& Howard, 1982). According to Jacobs (1996), with the increasing participation of women and LGBTQ+ individuals in campus life, the issue of creating a safe campus climate has become evident for these individuals who receive education, professional development and work in university environments. If a place is not safe for a group, it really is not safe 
for any group (Doan, 2007). Dilley (2002) states that university campuses are challenging environments for individuals who historically have not identified themselves as women and / or heterosexual. For this reason, campus grounds should be safe places for everyone, dark areas should be arranged making sure they are neither too crowded nor secluded (Newman, 1996).

The two countries that are the focus of our study, the United States of America and Turkey are naturally different in terms of higher educational background because of the two countries' historical development. The American education system has come a long way since the foundation of Harvard University (History of Harvard, 2019) in 1636 and the University of Georgia (History of UGA) in 1785. In Turkey the 'Darül Fünun' the first model of the modern Turkish University system was founded in 1846 (Dölen, 2008) and Bilkent the first private university was founded in 1984 (Tapu, Taze, Şiri, İlker Şendil, \& Terzioğlu, 2012). Students who have completed 12 years of education in both countries can move on to higher education. In the USA students are expected to get passing grades from standard university entrance exams such as GRE, GMAT, SAT and language exams such as IELTS and TOEFL which international students are additionally subjected to (Applying for Admission to a U.S. Program, 2019). There are US universities and colleges that accept these exams as well as higher education institutions that set their own admission standards. Students are also subjected to different criteria such as letters of recommendation, intention letter, voluntary activities outside the school and a successful GPA (What Colleges are Looking for in a Successful Applicant, 2019). In Turkey, university entrance procedures are implemented by Measurements, Selection and Placement Center (ÖSYM) as a central exam. At the end of this exam students calculate their cumulative of the exam score and the secondary education achievement score, list the departments and universities they would like to be placed in schools according to this cumulative score (Yeni Üniversiteye Giriş Sistemi, 2019).

The university is not only an educational institution, but also a social space where real life rules are experienced. The emerging adulthood and adulthood periods and habits gained during this period have a great impact on directing the individual's future life and career development (Gallian, Barnett, Brennan, \& Israel, 2010). For this reason, universities aim to establish a campus climate which is free from exclusion and discrimination and that has an unbiased environment for all. However, negative experiences can be encountered, witnessed, or experienced on campus. Discrimination based on gender, sexual harassment and assault are among these and are one of the consequences of gender inequality. Research show that gender-based discrimination and violence occur at various levels, including students, civil servants, and academic staff. For example, a study by Fisher, Cullen and Turner (2000) revealed that 20-25\% of female college students in United States have experienced sexual harassment or assault. Another study conducted in the United States (Krebs, Lindquist, Warner, Fisher, \& Martin, 2007) reveals that 19\% of female students are exposed to sexual harassment and assault at least once in their university lives. Cantor et al. (2015) shows that $47.7 \%$ of students have been subjected to sexual harassment at least once and $9.8 \%$ have been subjected to dating harassment after starting university. In studies conducted in Turkey it has been demonstrated that individuals have experienced or witnessed different types of sexual harassment on campus (Yiğitalp, Ertem, \& Özkaynak, 2007) (Yumuşak \& Şahin, 2014). According to a study, 58.5\% of university students in Turkey have at least once experienced harassment or sexual assault on their campus (Siyez, et al., 2018). Both in United States and Turkey, the students who are likely to be harassed and discriminated based on gender are female students and faculty (Kalaca \& Dündar, 2010). The main argument is that individuals who do not share their negative experience with their environment or institutions do not feel safe inside the campus or even disrupt their education experience (Kayacl, 2014). Therefore, the prevention and monitoring studies within universities on sexual harassment and assault crimes on their campuses are among the most important studies within the framework of GFCC. On the other hand, social media has also played a strong role in the appearance of gender-based discrimination in universities over the past decade. Especially in sexual harassment and assault cases where the patriarchal rules and laws cannot be surpassed, social media exposure is used. The feminist and LGBTQ+ groups are using social media very effectively in both countries, viral hashtags such as; \#ErilAkademiyeDurDe (\#StopPatriarchalAcademy), \#believesurvivors and \#timesup are used to create momentum. In this article, we focus on examining the institutional studies of universities only, leaving the research on usage of social media and the necessity and effectiveness of exposure for another study.

\section{MATERIALS AND METHODS}

This article is a study focused on the practices carried out by universities so that individuals can feel safe on university campuses and continue their studies in an unbiased climate. Our research has a Bell Hooks point of view. 
Three groups of sources were used in the review: official websites of universities, research and publications on the subject, and conference reports. The first group of data was collected in 2018-2020 by scanning official websites of selected universities. For the research and publications related to the subject, we used five keywords in Turkish and English (sexuality, campus climate, women friendly campus, gender, equality) in the academic search engines such as; Jstor, Academia, Wiley Online Library, APA, AAUW.org, Mendeley, Google Scholar. Research studies are specifically focused on Turkish and American universities publications. In the third group of official reports and the decoded texts of 'Against Sexual Harassment' seminars have also been observed.

The research for this article is limited with the applications that are sampled from USA and Turkish universities. The two countries that have been studied mainly are two countries with demographical differences. On the other hand, similar problems are observed in campus experiences, similar studies are carried out in the context of GFCC, although their intensity is different. The USA is an interesting case study, considering that the definition of campus climate is commonly seen in American literature and it is the country where the most research on the topic is done (Sandler \& Hall, 1986). Turkey on the other hand is country who has relatively just started on the issue.

The issue of sexual harassment and assault is a common campus problem in both countries, and research appears to be concentrated on this issue.

The research for this article covers the institutional studies of universities within the framework of GFCC, academic units carrying out scientific research and studies are excluded from the study. The gender and women's studies undergraduate/graduate departments at universities and the studies produced there are of great importance in creating a gender conscious climate. The first women's studies academic unit in the USA was established in the 1969-70 academic year, and over 600 universities have been opened to this date (Jacobs, 1996). The first women's studies lecture was given in 1993-94 academic year in Turkey and 19 universities have opened such lessons so far (Savaş, Ertan, \& Yol, 2018). These are academic units; Although they organize conferences and training sessions, they are mostly not an active action unit therefore it has been excluded from the review area of our article.

Our article covers the practices carried out in universities in the 2018-2019 academic year. Universities are selected in terms of the studies and practices on GFCC, not by the region they are located, subject or size. Therefore, it can be stated that purposeful sampling is used. The practices of the selected universities are examined according to on their internet sites. Special groups, individuals, international organizations, action groups, etc. that work or act on academic life and experiences on and off campus were excluded from this review. In this article, only the studies done by the universities for the GFCC are taken as focus points.

For this article ten American universities that fit the ranking criteria's best according to 2019100 Universities in The World with Gender Equality (Times Higher Education, 2019) and Pride Index (Pride Index, 2019) were chosen. From Turkey 10 universities who have active women's and gender issues research centers and universities who work on the GFCC topic were chosen. Since Turkey does not have a ranking and/or measurement criterion on this topic, considering their studies and actions on gender related issues the universities that have taken a leading role have been chosen. In the selection of cases, attention was paid to the balanced distribution of public and private universities for both countries. The names of the universities are not mentioned in the research for ethical reasons, the studies are exemplified.

\section{RESULTS AND DISCUSSIONS}

Although gender issues on campus seems to show similarities in both countries, action that is taken in such cases are of different densities. Units organizing the studies also vary; these are sometimes the university administrations, sometimes the university's gender and women's research and implementation centers and sometimes the leading academics working on this subject.

Considering the findings obtained in the research, it has been seen that the studies carried out by universities to establish GFCC can be presented under three headings:

- Gender climate and campus rules (policy documents and orientation / gender lessons),

- Dormitories and accommodation, Coed and GIH,

- Prevention and support activities against sexual harassment and assault.

\section{Gender climate and campus rules}


To establish a GFCC, universities first declare their own attitudes I institutionally, set rules and follow their implementation. In this context, policy documents and orientation/gender lessons can be mentioned.

\section{Policy documents}

Both Turkish and American universities plead their approach against gender discrimination and its consequences with a policy document. Almost every university in United States whereas a small number of universities in Turkey has a policy document.

Universities in the USA have policy documents that include the necessary rules for the use of space in campus units and the regulation of relationships between individuals, and the prevention and monitoring of any negative situation (sexual harassment and assault, exclusion, etc.). These documents set the standards for and disclose; what would the attitude of the university be against an unwanted situation mentioned in these documents, what are the actions that are not tolerated on campus, what kind of action would be followed in case of an undesirable situation and which offices and officers etc. should be contacted. These documents set out prevention and monitoring strategies by clearly drawing on-campus living rules. It has been seen in the review that there is no standard or common text for these documents in US universities. Each university has prepared its own text with its own title. For example, in the document titled "University Policy: Discrimination and Sexual Harassment Policy" adopted in 2011, the American University clearly identified all kinds of discrimination, sexual harassment, assault and stalking issues, and indicated which offices to apply in such undesirable situations (American University, 2019). In Harvard University's "Sexual and Gender-Based Harassment Policy" document, besides definitions, measures to be taken are also specified (Sexual and Gender-Based Harrassment Policy).

In Turkey, a small number of universities have a policy document with the framework of GFCC, studies on this subjected started first in the year 2010. It can be stated that Ankara University, Boğaziçi University, Sabancl University are examples and pioneers in this regard, the first policy documents dates back to 2011 (Cantek, 2013). These documents, which are prepared to prevent gender discrimination, consequences and reveal the attitude of universities, generally include definitions of sexual harassment and assault (Belkıs \& Siyez, 2018). For example, Ankara University is free from sexual harassment and assault in the document titled "Policy Document against Sexual Abuse and Sexual Assault", By stating that it is aimed to establish an academic and professional environment, these actions have been defined and it has been emphasized that the principles of confidentiality, care and trust will be followed in the studies to be carried out on the subject (AU, 2020).

On the other hand, Middle East Technical University emphasized 'gender equality' and 'Equality in gender and Strategies' by emphasizing 'equality between men and women', and issues such as gender equality in administrative assignments and academic appointments and promotions in order to create equal representation in campus management and life and to raise awareness about it. the university's attitude with definitions of sexual harassment and assault) (ODTU, 2017).

It is seen that various ideas and suggestions have been expressed in the Seminars on Combating Sexual Abuse and Attack Prevention and Cooperation for the development of these documents. It was stated that the policy documents should cover not only academics and students but also all the individuals on campus, the attitude of the university should be revealed more clearly, and the mediation which was completely disabled with the Istanbul Convention in terms of sexual harassment and crimes should be removed from these documents (1. Çalıştay raporu). In the 4th seminar in 2014, it was suggested that universities prepare a policy, directive, and regulation according to their own situation and conditions instead of referring to YÖK legislation. It is clearly seen in the seminar reports that academics working on this subject have created a strong network of solidarity and cooperation both among themselves and their universities (6. Çalıstay raporu). In addition, in the 2 nd, 7 th and 15 th seminars, it was discussed whether a common policy document could be prepared for all universities with a centralized approach, and instead of creating a common document, the idea of each university to prepare its own policy document was decided by considering its own circumstances. It can be stated that the said policy documents have different titles and different details for each university.

The definitions and punishments of exclusion and discrimination against sexuality, race or other variables, sexual harassment and assault, and punishments are explicitly included in the national laws of both countries, such as CEDAW, the Council of Europe Convention (Istanbul Convention). In their policy documents, universities emphasize that national and international legislation is based on the events that would take place within the campus. Civil Rights Acts, Title IX are shown as the basis for the documents of US universities. Title IX is the law adopted in the framework of educational changes in 1972. This law prohibits federally funded educational institutions from discriminating against students or employees based on gender. Civil Rights Acts, which has various stages, are also 
What is Being Done for A Gender-Friendly Campus Climate? United States and Turkey as A Case

highlighted in these documents (Sexual and Gender-Based Harrassment Policy). In the documents of Turkey's penal code 102-105 universities, higher education institutions have fulcrum shown Disciplinary Regulations (DEKAUM, 2015). According to the documents the policy documents of United States seems to be more accessible and visible than the policy documents of Turkish universities.

\section{Orientation / gender lessons}

In both countries, gender courses are either compulsory or optional in the curriculum or in orientation studies to establish a GFCC. These are the lessons to raise awareness about gender equality. An example to this could be the Alcohol Education and Sexual Assault Prevention lessons at Clayton State University which is a university in the university system of Georgia USA; Students are trained in sexual assault prevention, taught behavior that students can contribute to the establishments of a healthy, consent-based romantic emotional relationship, and where a positive campus environment is defined (Prevention, 2020). In Turkey, the Higher Education Council (YÖK) in 2015 in the context of gender equality to GFCC established as a compulsory or elective course strongly recommended to be added to the curriculum (YÖK, 2015). It should also be stated that the researchers conducting on-campus studies on this issue emphasize that the YÖK document in question is an important basis (Uygur, et al., 2018). Before this initiative, while informing about gender in a small number of orientation programs at universities, it should be emphasized that these are only awareness education and the impact area is probably not profound. Again, within the context of the 2015 resolutions of YÖK, it is very important to recommend that university administrations be given gender awareness training.

\section{Dormitories and accommodation, Coed and GIH}

For classrooms, canteens, dining halls, gymnasiums, open spaces, toilets, private areas, dormitories, faculty room, administrative staff rooms, etc. to be considered of adequate GFCC standards all units must be equal and safe for all.

Accommodation places and dormitories are important units in terms of campus climate and where gender policy is visible. Genders being placed together or separated give clues about the gender policy followed. If it is analyzed in terms of student dormitories having private or shared dorms are connected to the local government in Turkey, and they are strictly segregated by gender (Abdulkadir, 1995). Dormitories are places where entry and exit times and usage rules are strictly determined, genders are in different buildings and this principle of separation is never opened to discussion. One of the most controversial issues within the framework of the GFCC in US universities is housing and the use of common spaces (Morris, 2016). Many of the US universities offer accommodation in two different understandings: co-ed dorms and gender inclusive housing (GIH) (Willoughby, Carroll, Marshall, \& Clark, 2009). An abbreviation of co-educational expression, coed means that men and women are educated in the same building and in the classroom (Oxford Dictionary). Coed dormitory is also used to identify dormitory forms where male and female individuals use the same building, for example, where floors are separated (Burrell, 25). GIH, on the other hand, refers to a housing alternative in which two or more students agree to share a multi-room house / suite / apartment regardless of gender (Housing, 2019). Dormitory policy seems beneficial in creating a campus climate that supports all students. It is stated that such lifestyles contribute to trans and queer students to express themselves and feel comfortable. Although many university dormitories are single-sex, $90 \%$ have at least one GIH option (Housing, 2019). It is possible to present GIH types in five different categories: different sex, apartment style, appointment by sexual identity in the same room, equally separated groups, single rooms (Krum, Davis, \& Galupo, 2013). GIHs show a different structure in each university, a standard cannot be mentioned. Tomer (2019) states that more than 150 universities offer dormitory facilities for students, regardless of gender and sexual orientation.

Another factor that can secure campus common areas is the areas that will provide natural surveillance. It is thought that it is less likely to experience unwanted behavior in places with a wide field of view, without closed or blind spots. The use of the S-entry layout in the private area, especially in the toilet and bathroom, prevents it from being an invisible area. It is also recommended to use ventilated doors for toilets instead of solid doors (Dorn, et al., 2014).

\section{Prevention and support activities against sexual harassment and assault}

Gender-based violence, sexual harassment and predatory acts are criminal offenses and they are punishable, as required by both domestic law and international agreements in Turkey and USA. Within this framework, on-campus support offices could be mentioned. 
Most US university campuses have an office and an officer within the university under the title of equality law in the title IX. The duties of this unit include subjects such as education programs, on-campus employment, and university admissions, and it also supports students, academic and administrative staff on non-discrimination based on gender. These units also undertook the application, support, and guidance in cases of undesirable situations such as sexual violence and sexual harassment (Harvard IX, 2019). In these studies, it is necessary to mention the efforts of Bernice Sandler, who was also exposed to gender discrimination at work, she is an important figure considered her contribution to title IX and the terms 'cold campus climate' and 'gang rape' she added to literature (Seelye, 2019).

In Turkey there is no special law or regulation covering crimes on campus (Sevük, 2005). In such a case, the application is made to the affiliated person in the academic/ administrative unit. Also Support Units Against Sexual Harassment (CTS) can be mentioned in small number of universities. These units, which work directly under the rectorate in some universities, and under the women's and gender research administrative center in some universities, were established to support students, academic or administrative staff who encounter such undesirable situations. The scope of this support is legal, medical, and psychological. The CTS Unit, which was established in about 10 universities by 2020, has been actively operating at Ankara University since 2011 (AU, 2020).

The Istanbul convention that has been signed by Turkey in 2011, 'Gender Conscious University Seminar' organized by the Council of Higher Education with the influence of the strong public opinion created by the brutal murder and rape of university student Özgecan Aslan in 2015 (Belkıs \& Siyez, 2018) and strong feminist academics such as Gülriz Uygur, Yıldız Ecevit and Ayșe Akın have been influential in these studies.

In Turkey, one of the most important studies that has been done by universities is the communication and cooperation seminars organized by the universities and faculty members working against sexual harassment and assault twice a year. Through these seminars, a ground is prepared to discuss what is being done in these units and what could be done in the units that will be established (Uygur, et al., 2018).

One of the strategies to prevent and monitor sexual harassment and assault within the scope of GFCC in USA universities is the panic button and emergency blue light poles. According to experts, students are also under high threat to such adverse conditions, especially in the first months of school. In such a case, solutions were also researched for students who could not call friends, family or even the police in their common areas. EMERGENCY inscription in fluorescent / blue colored boxes and poles have become a staple in almost every university. The rape and the killing of a university student named Jeanne Clery in 1991 has contributed greatly to the spread of this program, which started in Chicago University in 1989, and even the law (Clery Act) is referred to by this teenager (Jackson L. , 2019).

Poles seem to have lost their function in today's technologically focused campuses, and even some universities have removed these blue poles. For example, the University of Georgia removed these poles from the campus in 2004, while the University of Colorado canceled the emergency phones in 2015 and developed a free mobile application (Put a Lifeline in Your Hands, 2018).

As a prevention strategy against sexual harassment and assault at American universities, Green Point Violence Prevention Strategy can be mentioned in recent applications. The program is primarily designed to prevent dating violence, sexual violence and persistent follow-up situations in college and university settings. The results of the comparison between three universities that adopted the practice between 2010 and 2013 and two universities that did not, were favorably observed in favor of implementation (Green dot for colleges).

This strategy is a national program aimed at training students, administrative and academic staff to help prevent power-based personal violence cases (PBPV). (Grant, Mottet, \& Tanis, 2011).

\section{CONCLUSIONS AND RECOMMENDATIONS}

Universities are idealized institutions, but they are not ideal social environments. Research show that campuses are places open to sexual discrimination, sexual harassment and assault and these situations are continuously occurring on campus grounds. However, equal and safe conditions must be provided for everyone on campus, including students, administrative and academic staff; because equality is a right, a human right.

There is not a single cause of problems, nor can there be a single solution. Therefore, the solution of the problems caused by gender inequalities cannot be not be one-way. The direction of the struggle can sometime be from top to the bottom, and sometimes from bottom to the top; components of the struggle can sometimes be activists, student 
or academic groups, non-governmental organizations or universities or unions with their corporate identity. In this article, we took US and Turkey as study cases and we tried to review and examine what universities have been doing institutionally to promote a gender-friendly campus climate. This article was created with the information announced by universities within the framework of gender-friendly campus climate and the data collected by the author's own experiences and testimonies.

Although gender-based problems encountered on campuses of both countries are similar, their counter action practices and how intense they would be is different. On one hand, the gender approaches of societies, and on the other hand, the gender policies of the governments, therefore, the official institutions have an important impact.

It can be stated that although the struggle on some issues is persistent, some problems are fully and purposely ignored. It could be said that the studies in the USA date back to 1970, and the studies in the Turkey commenced to 2010. In our review, we saw that there are two igniting factors in the transformation of studies on gender-friendly campus climate into two institutional steps;

- Creating public opinion on the terrible individual events and putting pressure on the institutions.

- Women academics who are pioneers in accelerating corporate decisions. Strong feminist scientists such as Berenice Sandler, Yıldız Ecevit, Gülriz Uygur and Ayşe Akın have shown women's effective role in the struggle for gender equality in the university structure.

Another issue that draws our attention is the impact of central and official decisions on universities for GFCC regulations. Enactment of Crime Awareness and Campus Security Law in 1990 in the USA and The Institution of Higher Education, an organization that is connected to all universities in Turkey (YOK) organizing a seminar in 2015 concerning Gender Conscious University regulations can be called the official starting points. In other words, universities started to work on equality with the push of the local and federal government. This situation implies that a national gender policy is being worked on and exemplifies the top-to-bottom direction of the movement.

There is no standard implementation string for GFCC. Each university conducts studies according to its own conditions and priorities, but nevertheless policy documents and publications related to ethical life rules, security of campus area and places, emergency stations, dormitory and private area uses, sexual harassment and attack prevention and monitoring studies, women and some base topics such as gender research application centers can be mentioned. We think that this topography displays a structure that evokes feminism. Feminism also rests on the main topics of establishing gender equality and eliminating gender discrimination, however, regional needs come to the forefront in practice.

In this context, GFCC may show differences in application according to the conditions of the region, university, individuals, and places but it is common in principles. The first important step for GFCC is the university's announcement of campus rules and attitude. This is announced in Policy Papers, the titles of which are different for each university.

It is understood that on-campus trainings are at great importance under the GFCC. It seems important to remember that exchange of knowledge within the scope of orientation courses, seminars given to university administrations or gender courses is an awareness training. Because attitude towards gender equality is not something that can easily change with practical applications, there may be discrepancies between ideas and attitudes (Siyez, et al., 2018). Therefore, it can be thought that these courses support awareness in the context of gender. It can also be suggested to conduct impact assessment studies on these training sessions, seminars, and lessons.

The corresponding option to US Coed and Gender Inclusive Housing in Turkey is entirely based on the student's sex. Here, it can be thought that the cultural structure directly affects the life of the university, so the dominant gender policy is effective in the campus climate. So, it is the belief that gender-based inequality will be eliminated from campus environments with these studies? Considering the following questions can provide a more realistic questioning:

How sincere are universities for creating a gender-friendly campus climate?

Does the gender policy have a national or cultural structure, or can institutions act independently of the big picture? Would there be still studies and still be carried out under the GFCC, if there were not any murders? What would happen if there were not any strong feminist women academics working for gender equality?

We think there is a need for field research seeking answers to these questions. 


\section{SOURCES OF FUNDING}

This research received no specific grant from any funding agency in the public, commercial, or not-for-profit sectors.

\section{CONFLICT OF INTEREST}

The author have declared that no competing interests exist.

\section{ACKNOWLEDGMENT}

We would like to thank all the leading academics who work to create an equal campus climate for everyone and who risk everything for this purpose.

\section{REFERENCES}

[1] Abdulkadir, T. (1995). Türkiye'de yükseköğrenim yurtlarının gelişimi. Kuram ve Uygulamada Eğitim Yönetimi , 3 (3), 465-474.

[2] Acar, F., \& Ertürk, Y. (2011). Kadının insan hakları: uluslar arası standartlar, kazanımlar, sorunlar. In S. Sancar (Ed), Bir Arpa Boyu... 21. Yüzyıla girerken Türkiye'de Feminist Çalışmalar. Prof. Dr. Nermin Abadan Unat'a Armağan (s. 281-304). İstanbul: Koç Üniversitesi Yayınları.

[3] American University. (2019). University Policy: Discrimination and Sexual Harassment Policy. Retrieved from: https://www.american.edu/policies/au-community/upload/disrimination-and-sexual-harassmentpolicy-09-05-19-final.pdf

[4] Ankara Üniversitesi. (2020). Cinsel Tacize ve Cinsel Saldırıya Karşı Destek Birimi. Retrieved from: http://cts.ankara.edu.tr/ankara-universitesi-cinsel-tacize-ve-cinsel-saldiriya-karsi-politika-belgesi/

[5] Belkıs, Ö., \& Siyez, D. (2018). Kadın hakları ve sorunları araştırma ve uygulama merkezi olmak: DEKAUM özelinde bir deneyim paylaşımı. In G. Uygur, H. Şimga, F. Ş. Cantek, A. Şimşek, D. Songur, S. Kalem, et al., Üniversitelerde Cinsel Taciz ve Saldırıyla Mücadele: CTS Çalışmaları (s. 67-76). Magosa: Doğu Akdeniz Üniversitesi Yayınevi.

[6] Burrell, J. (25, 05 2019). College Life: What Are Coed Dorm Rooms? Retrieved from: Https://Www.Thoughtco.Com/What-Are-Coed-Dorm-Rooms3570263

[7] Cantek, F. (2013). Ankara Üniversitesi Cinsel Tacize ve Saldırıya Karşı Destek Birimi (CTS) nedir? Nasıl çalışır? Mülkiye Dergisi , 37 (4), 231-253.

[8] Cantor, D., Fisher, B., Chibnall, S., Townsend, R., Lee, H., Bruce, C., et al. (2015). Report on the AAU campus climate survey on sexual assault and sexual miscnduct. Retrieved from: https://www.aau.edu/sites/default/files/\%40\%20Files/Climate\%20Survey/AAU_Campus_

Climate_Survey_12_14_15.pdf

[9] Chang, M. (2003). Racial differences in viewpoints about contemporary students amoung entering college students: fact or fiction. NASPA Journal, 40(4), 55-71.

[10] Dökmen, Z. (2010). Toplumsal Cinsiyet. İstanbul: İletişim Yayınları.

[11] Dölen, E. (2008). II. Meşrutiyet Döneminde Darülfünun. Osmanlı Bilimi Araștırmaları , 10 (1), 1-46.

[12] D'Augelli, A., \& Hershberger, S. (1993). African American undergraduates on a predominantly white campus: academic factors, social networks, and campus climate. The Journal of Negro Education, 62 (1), 67-81.

[13] DEKAUM . (2015, 11 09). YÖK Tutum Belgesi. Retrieved from: http://dekaum.deu.edu.tr/wpcontent/uploads/2016/06/Tutum-Belgesi.pdf

[14] Dilley, R. (2002). The problem of context in social and cultural anthropology. Language \& Communication , 22 (4), 437-456.

[15] Doan, P. (2007). Queers in the American City: Transgendered perceptions of urban space. Gender, Place $\S$ Culture , $14(1), 57-74$. 
What is Being Done for A Gender-Friendly Campus Climate? United States and Turkey as A Case

[16] Dokuz Eylül Üniversitesi. (2015, 12 08). DEKAUM (Dokuz Eylül Üniversitesi Kadın Hakları ve Sorunları Araştırma ve Uygulama Merkezi). Retrieved from: http://dekaum.deu.edu.tr/wpcontent/uploads/2016/05/DEU-CTS-politika-belgesi-1.pdf

[17] Dorn, M., Atlas, R., Schneider, T., Dorn, C., Nguyen, P., Satterly, S., et al. (2014, 11 19). Seven Important building design features to enhance school safety and security. Retrieved from: Safe Havens International: https://safehavensinternational.org/wpcontent/uploads/2014/12/Seven_Important_Building_Design_Features_to_Enhance_School_Safety_and_Sec urity-ISSSA_2014.pdf

[18] Fisher, B., Cullen, F., \& Turner, M. (2000). The Sexual Victimization of Colege Women. National Ins. of Justice, Department of Justice. Washington, DC.: Bureau of Justice Statistics.

[19] Gallian, S., Barnett, R., Brennan, M., \& Israel, G. (2010). The effects of gender role conflict on adolescent and emerging adult male resiliency. The Journal of men's studies , 18 (1), 3-21.

[20] Grant, J., Mottet, L., \& Tanis, J. (2011). Injustice at every turn: A Report of the National Transgender Discrimination Survey. Washington: National Center for Transgender Equality and National Gay and Lesbian Task Force.

[21] Green dot for colleges. (tarih yok). Alteristic. Retrieved from: https://alteristic.org/services/greendot/green-dot-colleges/

[22] Hernández , N., González, P., \& Sánchez, S. (2013). Gender and constructs from the hidden curriculum. Creative Education, 4 (12B), 89-92.

[23] Hutchinson, S., Raymond, K., \& Black, K. (2008). Factorial invariance of a campus climate measure across race, gender, and student classification. Journal of Diversity in Higher Education , 1 (4), 235-250.

[24] Jackson, L. (2019, 01 25). Emergency Blue-Light Phones Are a Symbol of Safety. Is Symbolism Worth Thousands? . Chronicle.

[25] Jackson, P. (1990). Life in classroom. Teacher College Press.

[26] Jacobs, J. (1996). Gender inequality and higher education. Annual Review of Sociology , 22 (1996), 153-185.

[27] Jenainati, C., \& Groves, J. (2007). Feminizm. İstanbul: NTV Yayınları.

[28] Jones, S., \& Abes, E. (2013). Identity development of college students: Advancing frameworks for multiple dimensions of identity. San Francisco, CA, US: Jossey-Bass.

[29] Kalaca, S., \& Dündar, P. (2010). Violence against women: The perspective of academic women. BMC Public Health , 10.

[30] Kayacı, Ü. (2014). Akademik ortamlarda psikolojik şiddet (mobbing) ve yılmazlık. Türk Eğitim Bilimleri Dergisi , 12 (2), 67-78.

[31] Krebs, C., Lindquist, C., Warner, T., Fisher, B., \& Martin, S. (2007). The campus sexual assault (CSA) study: final report. National Institüte of Justice. Washington, DC: National Institute of Justice, US Department of Justice.

[32] Krum, T. E., Davis, K. S., \& Galupo, M. P. (2013). Gender-inclusive housing preferences: A survey of collegeaged transgender students. Journal of LGBT Youth , 10 (1-2), 64-82.

[33] Lott, B., Reilly, M. E., \& Howard, D. R. (1982). Sexual assault and harassment: A campus community case study. Signs: Journal of Women in Culture and Society, 8 (2), 296-319.

[34] Magolda, M. (2009). The activity of meaning making: A holistic perspective on college student development. Journal of College Student Development .

[35] Miller, M., Anderson, R., Cannon, J., Perez , E., \& Moore, H. (1998). Campus racial climate policies: the view from the bottom up. Race, Gender, Class , 5 (2), 139-157.

[36] Morris, M. (2016). Five Things You Should Know About Gender Trends on Campus. Psychology Today .

[37] Newman, O. (1996). Creating defensible space. Washington: Rutgers University.

[38] Orta Doğu Teknik Üniversitesi. (2017, 10 13). Toplumsal Cinsiyet Eşitliği İlke ve Stratejiler Belgesi. Retrieved from: https://citob.metu.edu.tr/system/files/odtu_toplumsalcinsiyetesitligi_ilke_ve_stratejiler_belgesi.pdf

[39] Pascarella, E., \& Terenzini, P. (2005). How college affects student. Jossey-Bass.

[40] Puri, L. (2017, June). ECOSOC Coordination and Management Session. UN-Women. Retrieved from: https://www.unwomen.org/en/news/stories/2017/6/speech-ded-puri-ecosoc-coordination-andmanagement

[41] Put a LifeLine in Your Hands . (2018, 10 10). Colorado University. Retrieved from: https://oit.colorado.edu/news/16739 
[42] Rankin, S., \& Reason, R. (2005). Differing Perceptions: How Students of Color and White Students Perceive Campus Climate for Underrepresented Groups. Journal of College Student Development , 46 (1), 43-61.

[43] Reid, L., \& Radhakrishnan, P. (2003). Race matters: The relation between race and general campus climate. Cultural Diversity and Ethnic Minority Psychology , 9 (3), 263-275.

[44] Requirements for First Year and Transfer Students to complete AlcoholEDU and Sexual Assault Prevention Courses (formerly known as Haven/Haven Plus). (2020). Clayton State University. Retrieved from: https://www.clayton.edu/community-standards/Prevention

[45] Roommate Choice Gender-Neutral Housing' Housing. (2019). Boston University. Retrieved from: http://www.bu.edu/housing/assignments/gender-neutral-housing

[46] Savaş, G., Ertan, S., \& Yol, F. (2018). Türkiye'deki üniversitelerin kadın araștırma merkezleri profil araștırması. Elektronik Sosyal Bilimler Dergisi , 17 (68).

[47] Seelman, K., Woodford, M., \& Nicolazzo, Z. (2017). Victimization and microaggressions targeting LGBTQ college students: gender identity as a moderator of psychological distress. Journal of Ethnic and Cultural Diversity in Social Work: Innovation in Theory, Research and Practice , 26 (1-2), 112-125.

[48] Seelye, K. (2019, 01 08). Bernice Sandler, 'Godmother of Title IX', Dies at 90 . New York Times .

[49] Selingo, J. (2015, July 20). How many colleges and universities do we really need. Washington Post. Retrieved from: https://www.washingtonpost.com/news/grade-point/wp/2015-/07/20/how-many-colleges-anduniversities-do-we-really-need/

[50] Sevük, H. (2005). 5237 Sayılı Türk Ceza Kanunu'nda Cinsel Saldırı ve Cinsel Taciz Suçları. Türkiye Barolar Birliği Dergisi , 18 (57), 243-282.

[51] Sexual and Gender-Based Harrassment Policy. (tarih yok). (H. University, Prodüktör) Harvard University Police Department. Retrieved from: https://www.hupd.harvard.edu/sexual-and-gender-based-harassmentpolicy

[52] Siyez, D., \& Yusupu, R. (2015). Üniversite öğrencilerinde kariyer uyumlulugu ve kariyer iyimserliğinin cinsiyet rolü değişkenine göre incelenmesi. İş Güç Endüstri İlişkileri ve İnsan Kaynakları Dergisi , 17 (1), 78-88.

[53] Siyez, D., Belkıs, Ö., Esen, E., Soylu, Y., Firuzan, E., Güney, M., et al. (2018). Cinsel taciz ve saldırıya karşı birincil önleme stratejilerinin geliştirilmesi. DEKAUM (Dokuz Eylül Üniversitesi Kadın Hakları ve Sorunları Araştırma ve Uygulama Merkezi). İzmir: Dokuz Eylül Üniversitesi Bilimsel Araştırma Birimi.

[54] Squire, D., \& Norris, L. (2014). Supporting students in the margins: establishing a first-year experience for LYBTQA students. Journal of Student Affairs Research and Prackice , 51 (2), 195-206.

[55] Tapu, S., Taze, M., Şiri, H., İlker Şendil, A., \& Terzioğlu, E. (2012). Türkiye'de ilk vakıf üniversitesi olarak Bilkent Üniversitesi'nin kuruluşu. Selim Tezcan, HIST 200-06 History of Turkey (2011-2012 spring). Ankara: Bilkent Universitesi.

[56] Tomer, J. (2019, 05 11). Co-ed dorms: sleeping together. 06 10, 2020 tarihinde College Express. Retrieved from: https://www.collegexpress.com/articles-and-advice/student-life/articles/living-campus/co-eddorms-sleeping-together/

[57] Uygur, G., Şimga, H., Cantek, F., Şimşek, A., Songur, D., Kalem, S., et al. (2018). Üniversitelerde cinsel taciz ve saldırıyla mücadele: CTS çalışmaları. (G. Uygur, \& H. Şimga, Ed) Magosa: Doğu Akdeniz Üniversitesi Yayınevi.

[58] Walters, M. (2005). A very short introduction. Oxford University Press.

[59] Willoughby, B., Carroll, J., Marshall, W., \& Clark, C. (2009). The decline of in loco parentis and the shift to coed housing on college campuses. Journal of Adolescent Research , 24 (1), 21-36.

[60] Yiğitalp, G., Ertem, M., \& Özkaynak, V. (2007). Üniversite öğrencilerinin şiddet konusunda deneyimleri ve bu konudaki görüşleri. TSK Koruyucu Hekimlik Bülteni , 6 (2), 131-136.

[61] Yumuşak, A., \& Şahin, R. (2014). Flörtte şiddete yönelik tutum ölçeklerinin geçerlilik ve güvenilirlik çalışması. Elektronik Sosyal Bilimler Dergisi , 13 (49), 233-252.

[62] Zimmerman, A., \& Herridge, A. (1970, Jenuary 1). Campus climate and the theory of gender performativity: implications for research and policy . Retrieved from: https://www.igi-global.com/chapter/campus-climateand-the-theory-of-gender-performativity/213429 